\title{
Serum high-sensitivity C-reactive protein levels in co- morbid patients with type-2 diabetes mellitus and periodontal disease
}

\author{
Tan Jiawei ${ }^{1 \star}$, Pan Lulu ${ }^{2 \star}$, Xu Guochao ${ }^{1}$, Xiang Lixin $^{1}$ \\ ${ }^{1}$ Department of Stomatology, Zhejiang Hospital, Hangzhou City 310013, ${ }^{2}$ Department of Oral and Maxillofacial Surgery, The \\ First Affiliated Hospital of Wenzhou Medical University, Wenzhou City 325000, Zhejiang Province, China
}

*For correspondence: Email: sn1237@163.com; Tel: +86-15158619497

\begin{abstract}
Purpose: To investigate the relationship between serum levels of high-sensitivity C-reactive protein (hsCRP) and the severity of periodontal disease in diabetics with periodontitis.

Methods: Ninety patients were recruited for this study. They were divided into three groups, namely, group 1 (30 patients with type 2 diabetes mellitus (T2DM) and periodontal disease), group II (30 patients with T2DM only) and control (30 healthy individuals). Serum levels of hs-CRP and glycosylated hemoglobin ( $H b A c)$ were determined. Moreover, blood glucose (BG) and insulin (FNS) levels were determined in the fasted state, and their values used to compute insulin resistance index (Homa-IR).

Results: Serum levels of FNS, FPG, HbAc and Homa-IR in group I patients were significantly higher ( $p$ $<0.05)$ than those of control group. While the levels of $B G$ and Homa-IR in the serum of patients in groups I and II were significantly higher $(p<0.05)$ than those of control, marked reductions were seen in their values in group II, relative to group I. The serum levels of hs-CRP in group I and II were significantly increased $(p<0.05)$ relative to control, but were lower in group II than in group I $(p<0.05)$. Homa-IR was positively correlated with serum hs-CRP, FNS, BG, HbAc, and Homa-IR in groups I and II. Results from multiple regression analysis revealed significant effects of hs-CRP and HbAc on HomaIR.
\end{abstract}

Conclusion: Serum levels of hs-CRP in patients with T2DM and periodontitis are closely related to disease severity, insulin resistance and blood glucose level.

Keywords: Type-2 diabetes mellitus, Periodontal disease, High-sensitivity C-reactive protein, Blood glucose, Insulin resistance, Correlation

This is an Open Access article that uses a funding model which does not charge readers or their institutions for access and distributed under the terms of the Creative Commons Attribution License (http://creativecommons.org/licenses/by/4.0) and the Budapest Open Access Initiative (http://www.budapestopenaccessinitiative.org/read), which permit unrestricted use, distribution, and reproduction in any medium, provided the original work is properly credited.

Tropical Journal of Pharmaceutical Research is indexed by Science Citation Index (SciSearch), Scopus, International Pharmaceutical Abstract, Chemical Abstracts, Embase, Index Copernicus, EBSCO, African Index Medicus, JournalSeek, Journal Citation Reports/Science Edition, Directory of Open Access Journals (DOAJ), African Journal Online, Bioline International, Open-J-Gate and Pharmacy Abstracts

\section{INTRODUCTION}

Studies have shown that insulin resistance and abnormal expression of inflammatory factors are the major features of T2DM [1]. High-sensitivity C-reactive protein (hs-CRP) is one of the common non-specific inflammatory markers that can effectively predict the incidence of cardiovascular disease and T2DM [2, 3]. Periodontitis is one of the risk factors for progression of T2DM [4]. However, not much is known about the relationship between serum 
levels of hs-CRP and the severity of periodontal disease in patients with T2DM and periodontitis. The aim of this study was to investigate the relationship between serum levels of hs-CRP and the gravity of periodontitis in patients with T2DM and periodontitis.

\section{EXPERIMENTAL}

\section{Materials}

The immuno-chromatography kits used in this study was purchased from Wuhan Mingde Biotechnology Co., Ltd.

\section{General characteristics of subjects}

Ninety patients participated in this study. They were divided into three groups: group I (thirty patients with T2DM and periodontal disease), group II (thirty patients with T2DM only), and the control group (30 healthy individuals). Approval for this study was given by the Ethical Committee of Stomatology Department, Zhejiang Hospital, Hangzhou City, Zhejiang Province, 310013, China. The study was carried out in conformity with the amended Helsinki Declaration of 1964 [5].

\section{Inclusion criteria}

The inclusion criteria used were: (1) patients with periodontitis who presented with severe gingivitis, attachment loss $>5 \mathrm{~mm}$, and depth of adventitia bag > $6 \mathrm{~mm}$; (2) patients with T2DM consistent with the World Health Organization (WHO) classification and diagnostic criteria [6]; (3) patients with alveolar bone resorption more than $1 / 2$; (4) patients who did not receive antibiotics 6 months before the commencement of the study; and (5) the patients who agreed to participate in the study by signing written informed consent.

\section{Exclusion criteria}

The excluded patients were: (1) patients who had endocrine system diseases that affect lipid and glucose metabolism; (2) patients who had heart, liver or kidney disease; (3) patients with malignant tumors; (4) lactating or pregnant patients; and (5) patients who voluntarily withdrew from the study.

\section{Biochemical assays}

Fasting venous blood $(3 \mathrm{ml})$ was collected from each patient and subjected to centrifugation for $10 \mathrm{~min}$ at $3000 \mathrm{~g}$ to obtain serum used for immuno-chromatography. Levels of BG, HbAc and FNS were determined in the serum. The calculation for Homa-IR was done using the formula:

Homa-IR $=(F N S \times B G) / 22.5 \ldots \ldots \ldots(1)$

\section{Statistical analysis}

The results obtained are presented as mean \pm standard error of the mean (SEM). Comparison between groups was done with Student's $t$-test, using SPSS 20.0. Statistical significance was fixed at $p<0.05$.

\section{RESULTS}

\section{General characteristics of subjects}

There were no significant differences in sex and age of patients in the three groups (Table 1). The characteristics of the patients are shown in Table 1 , while the clinico-pathological features of periodontitis are shown in Figure 1.

Table 1: General clinical data of subjects

\begin{tabular}{|c|c|c|c|c|c|}
\hline \multirow{2}{*}{ Group } & \multirow{2}{*}{ Cases } & \multicolumn{2}{|c|}{ Sex } & \multirow{2}{*}{$\begin{array}{c}\text { Age } \\
\text { (years) }\end{array}$} & \multirow{2}{*}{$\begin{array}{c}\text { BMI } \\
\left(\mathrm{kg} / \mathrm{m}^{2}\right)\end{array}$} \\
\hline & & Male & Female & & \\
\hline I & 30 & 17 & 13 & $\begin{array}{c}56.63 \pm \\
8.38\end{array}$ & $\begin{array}{c}22.31 \pm \\
8.32\end{array}$ \\
\hline II & 30 & 18 & 12 & $\begin{array}{c}56.39 \pm \\
9.03\end{array}$ & $\begin{array}{c}23.04 \pm \\
7.93\end{array}$ \\
\hline Control & 30 & 16 & 14 & $\begin{array}{c}57.88 \pm \\
10.28\end{array}$ & $\begin{array}{c}23.31 \pm \\
8.06\end{array}$ \\
\hline
\end{tabular}
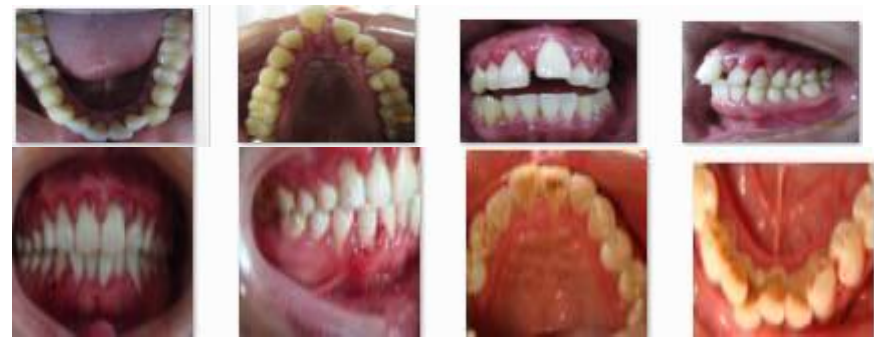

Figure 1: The manifestations of periodontitis

\section{Serological profile}

The serum levels of FNS, BG, HbAc and HomaIR in group I patients were significantly higher ( $p$ $<0.05$ ) than those in control group. While the serum levels of BG and Homa-IR in patients in groups I and II were significantly higher $(p<$ 0.05 ) than those of control, they were markedly lower in group II than in group I (Table 2).

\section{Serum levels of hs-CRP}

The serum levels of hs-CRP in groups I and II were significantly higher $(p<0.05)$ than those of 
Table 2: Serological profiles of the groups studied

\begin{tabular}{lccccc}
\hline Group & Cases & FNS $(\mathbf{m U} / \mathbf{L})$ & FPG $(\mathbf{m M})$ & HbAc $(\%)$ & Homa-IR \\
\hline I & 30 & $8.48 \pm 1.93^{*}$ & $9.12 \pm 1.21^{\text {*\# }}$ & $9.78 \pm 1.88^{\text {*\# }}$ & $1.52 \pm 0.28^{\text {*\# }}$ \\
II & 30 & $7.03 \pm 1.21$ & $7.41 \pm 1.93^{*}$ & $5.79 \pm 1.25$ & $0.94 \pm 0.19^{*}$ \\
Control & 30 & $6.12 \pm 1.38$ & $5.32 \pm 0.64$ & $4.19 \pm 1.02$ & $0.68 \pm 0.22$ \\
\hline
\end{tabular}

${ }^{\star} P<0.05$, compared to control group; ${ }^{\#} p<0.05$, compared to group $B$

Table 3: Serum levels of hs-CRP

\begin{tabular}{lcc}
\hline Group & Cases & $\begin{array}{c}\text { hs-CRP } \text { ( } \mathbf{m g} / \mathbf{L} \\
\text { ) }\end{array}$ \\
\hline I & 30 & $6.47 \pm 1.28^{\star \#}$ \\
II & 30 & $2.71 \pm 0.59^{\star}$ \\
Control & 30 & $0.82 \pm 0.28$ \\
\hline${ }^{*} P<0.05$, relative to control; ${ }^{\#} p<0.05$, relative to \\
group II
\end{tabular}

control, but were significantly reduced $(p<0.05)$ in group II relative to group I (Table 3 ).

\section{Severity of periodontitis correlated with serum hs-CRP}

The serum levels of hs-CRP in groups $A$ and $B$ were positively correlated with their FNS, FPG, $\mathrm{HbAc}$ and Homa-IR levels. Results from multiple regression revealed significant influence of hsCRP and $\mathrm{HbAc}$ on Homa-IR (Table 4).

Table 4: Analysis of correlation between serum hs$\mathrm{CRP}$ and serological parameters

\begin{tabular}{lcc}
\hline \multirow{2}{*}{ Variable } & \multicolumn{2}{c}{ hs-CRP } \\
\cline { 2 - 3 } & $\mathbf{R}$ & $\boldsymbol{P}$ \\
\hline FNS & 0.784 & 0.000 \\
BG & 0.869 & 0.028 \\
HbAc & 0.819 & 0.000 \\
Homa-IR & 0.573 & 0.000 \\
\hline
\end{tabular}

\section{DISCUSSION}

Under physiological or pathological conditions, the liver synthesizes and secretes large amounts of hs-CRP as an acute phase protein which serves as a non-specific biomarker of inflammation [7]. The resultant increase in hsCRP level can effectively trigger a number of signaling pathways, stimulate the inflammatory response, and reduce the sensitivity of peripheral tissues to insulin [8]. As a biologically sensitive marker of systemic disease, hs-CRP is affected by factors such as systemic infection, obesity and immune system diseases [9]. There were higher levels of serum FNS, FPG, $\mathrm{HbAc}$ and Homa-IR in group I patients than in the control group. While the levels of FPG and Homa-IR in the serum of patients in groups I and II were significantly higher than those of control, they were significantly reduced in group II, when compared to I. The serum level of hs-CRP in group II was significantly increased relative to control, but was significantly lower than that of group I.

These results suggest that T2DM may be closely related to inflammation. Some studies have suggested that elevated tumor necrosis factor affects the phosphorylation of insulin receptor substrate (IRS), and enhances the formation and release of hs-CRP [10]. In addition, it has been reported that serum hs-CRP levels in patients are increased by simultaneous presence of T2DM and periodontal disease [10]. The results of this study are in agreement with reports of previous studies [11].

Studies have shown that the periodontal pocket ulcer area of patients with severe periodontitis could be as high as $72 \mathrm{~cm}^{2}$ or more, while in chronic periodontal tissue infection, the endotoxin produced by inflammatory cytokines and gram-negative bacteria can enter the systemic circulation, leading to acute inflammation [12-17]. In the present study, there was a positive correlation between serum hsCRP, FNS, BG, HbAc and Homa-IR in groups I and II patients. Results from multiple regression indicated that hs-CRP and $\mathrm{HbAc}$ significantly affected Homa-IR. Hence, high levels of hs-CRP in the serum of patients with T2DM and periodontitis may increase insulin resistance. Therefore, Hs-CRP can be used as a sensitive marker of inflammation.

\section{Limitations of the study}

The sample size used in this study was small. Thus, there will be need to expand the sample size in further studies and analyze the link amongst inflammation, Homa-IR and hyperglycemia.

\section{CONCLUSION}

The levels of hs-CRP in the serum of patients with T2DM and periodontitis are closely linked with the severity of periodontal disease, resistance to insulin, and blood glucose level. Thus, the drugs used can be guided possibly by monitoring the levels of hs-CRP in the serum of patients with T2DM. 


\section{DECLARATIONS}

\section{Conflict of Interest}

No conflict of interest associated with this work.

\section{Contribution of Authors}

We declare that this work was done by the author(s) named in this article and all liabilities pertaining to claims relating to the content of this article will be borne by the authors. All authors read and approved the manuscript for publication. $\mathrm{Xu}$ Guochao conceived and designed the study, Tan Jiawei, Xu Guochao, Xiang Lixin collected and analysed the data, while Tan Jiawei wrote the manuscript.

\section{REFERENCES}

1. Portillo $S P$, Bril F, Maximos M, Lomonaco R, Biernacki $D$, Orsak B, Subbarayan S, Webb A, Hecht J, Cusi K. High prevalence of nonalcoholic fatty liver disease in patients with type-2 diabetes mellitus and normal plasma aminotransferase levels. J Clin Endocrinol Metab 2015; 100(6): 2231-2239.

2. Ming J, Xu S, Gao B, Liu G, Ji Y, Yang F, Jia Y, Fang Y, Ji $Q$. Non-alcoholic fatty liver disease predicts type-2 diabetes mellitus, but not prediabetes, in Xi'an, China: a five-year cohort study. Liver Int 2015; 35(11): 2401 2407.

3. Zaccardi F, Kurl S, Pitocco D, Ronkainen K, Laukkanen $J A$. Serum fructosamine and risk of type-2 diabetes mellitus among middle-age Finnish men: a 23-year population-based prospective study. Acta Diabetol 2015; 52(1): 161-166.

4. Fox CS, Golden SH, Anderson C, Bray GA, Burke LE, de Boer $I H$, Deedwania P, Eckel RH, Ershow AG, Fradkin $J$, et al. Update on prevention of cardiovascular disease in adults with type-2 diabetes mellitus in light of recent evidence: a scientific statement from the American Heart Association and the American Diabetes Association. Circ 2015; 132(8): 691-718.

5. World Health Organization. Declaration of Helsinki. Br Med J 1996; 313(7070): 1448-1449.

6. Cai WC, Zhang JY. New criteria for classification and diagnosis of diabetes mellitus. Ningxia Med J 2000; 22(8): 510-510.

7. Effoe VS, Correa A, Chen H, Lacy ME, Bertoni AG. Highsensitivity $C$-reactive protein is associated with incident type-2 diabetes mellitus among African-Americans: the
Jackson Heart Study. Diabetes Care 2015; 38(9): 16941700.

8. Lepojarvi ES, Piira OP, Kiviniemi AM, Miettinen JA, Kenttä T, Ukkola O, Tulppo MP, Huikuri HV, Junttila MJ. Usefulness of highly sensitive troponin as a predictor of short-term outcome in patients with diabetes mellitus and stable coronary artery disease. Am J Cardiol 2015; 117(4): 515-521.

9. Geng J, Lu W, Hu T, Tao S, Zhang H, Chen J, Bu Y, Ma $S$, Wang $B$. Subclinical hyperthyroidism increases risk of coronary heart disease events in type-2 diabetes mellitus. Endocrine 2015; 49(2): 1-3.

10. Kokil GR, Veedu RN, Ramm GA, JB Prins, HS Parekh. Type-2 diabetes mellitus: limitations of conventional therapies and intervention with nucleic acid-based therapeutics. Chem Rev 2015; 115(11): 4719-4743.

11. Ashraf JM, Arfat MY, Arif Z, Ahmad J, Moinuddin, Alam $K$. A clinical correlation of anti-DNA-AGE autoantibodies in type-2 diabetes mellitus with disease duration. Cell Immunol 2015; 293(2): 74-79.

12. Ap VDW, Vand GY, Westerink J, Nathoe HM, Visseren $F L$. Effect of statin therapy on incident type-2 diabetes mellitus in patients with clinically manifest vascular disease. Am J Cardiol 2015; 115(4): 441-447.

13. Diabetologia [homepage on the Internet]. SpringerVerlag; c 2008 [cited 2018 Aug 22]. Available from: https://link.springer.com/article/10.1007\%2Fs00125008-1117-6.

14. Huang $X$, Wang J. Up-regulation of endogenous leptin improves human mesenchymal stem cell survival ability in vitro and this cells protect fatal cardial myocytes from apoptosis, 2012 [cited 2018 Aug 22]. Available from: https://heart.bmj.com/content/98/Suppl_2/E167.2.

15. Karsten K, Louisa S, Umile GL, Peter M. Eccentric exercises for the management of tendinopathy of the main body of the Achilles tendon with or without the AirHeel ${ }^{\text {TM }}$ Brace. A randomized controlled trial. A: Effects on pain and microcirculation. Disabil Rehabil 2009; 7: 1685-1691.

16. Esophageal and Extradigestive Diseases [homepage on the Internet]. Wiley Online Library; c 2006 [cited 2018 Aug 22]. Available from: https://onlinelibrary.wiley. com/doi/abs/10.1111/j.1523-5378.2006.00419_10.x.

17. Research from Gazi University Has Provided New Data on Obstructive Sleep Apnea (Report) [homepage on the Internet]. Obesity, Fitness \& Wellness Week; c 2012 [cited 2018 Aug 22]. Available from: https://www.turnitin. com/viewGale. $a s p ? r=14.6287961540601 \& s v r=47 \&$ lang $=e n \_u s \& o i d=84725626 \& k e y=3 d 3 b a a b 37 f 5 b 4 f 9 d f b a 270$ 9631c9df8d. 